\title{
Depression, Anxiety and Stress in Egyptian Patients with Chronic Liver Diseases
}

\author{
Amany M. AbdAllah ${ }^{*}$., Mahmoud A. Sharafeddin ${ }^{2}$ \\ ${ }^{1}$ Family Medicine department, Faculty of Medicine, Zagazig University, Egypt. \\ ${ }^{2}$ Internal Medicine department, Faculty of Medicine, Zagazig University, Egypt
}

\begin{abstract}
:
Background: Patients with chronic liver disease (CLD) can suffer from varied degrees of depression and anxiety. Objectives: to determinate the frequency and severity of depression, anxiety and stress in patients with CLD and to identify the relation between sociodemographic, diseasespecific factors and depression, anxiety and stress among those patients.

Methods: A cross-sectional study was done in internal medicine outpatient clinic, Zagazig university hospital in the period from June to December 2018. A questionnaire including personal characteristics and etiology of CLD was filled in. The diagnosis of CLD was confirmed by using combination of clinical signs, symptoms, laboratory investigations and ultrasonography. The severity of liver disease was quantified using modified Child-Pugh classification. Mental health was assessed using Depression Anxiety Stress Scale (DASS-21) questionnaire.

Results: More than one fourth of cases had mild depression while $16.5 \%$ of them had moderate depression. The same percentage reported extremely severe anxiety and severe stress. There are statistically significant differences between gender, patient education, ascites, child pough classification, comorbid diabetes and mean depression, anxiety and stress scores. Comorbid diabetes and decompensated cirrhosis significantly increase risk of depression by 3.84 and 17.7 folds respectively. Absence of comorbid hypertension and being illiterate were protective factors against anxiety or stress. Absence of diabetes protects against stress.

Conclusion: Psychiatric symptoms were frequent among patients with CLD. Comorbid diabetes and decompensated cirrhosis increase risk of depression while absence of hypertension and illiteracy were protective factors against both anxiety and stress symptoms.
\end{abstract}

Keywords: anxiety, depression, stress.

\section{Introduction:}

Chronic liver disease (CLD) encompasses a diverse spectrum of disorders, ranging from liver steatosis (alcoholic and non-alcoholic), hepatitis $\mathrm{B}$ and $\mathrm{C}$ virus infection, cirrhosis to other less common conditions. ${ }^{(1)}$ Due to their higher incidence and prevalence, these ailments have turned into a progressively noteworthy public health matter worldwide. ${ }^{(2)}$

Patients with CLD can suffer from varied grades of depression and anxiety. ${ }^{(3)}$ They can also have personality, sleep and further behavior and cognitive deficits. ${ }^{(4)}$
Psychosocial stressors are a contributing issue to such morbidity, and involve the adverse effect of diagnosis, anti-viral therapy, stigma, and concerns about disease progression or viral transmission. ${ }^{(5)}$

The proof about the presence of these symptoms in CLD patients is weighty because they have an adverse effect upon the illness course in the form of augmentation of physical symptoms, functional impairment, reduced treatment compliance, and impaired quality of life. $^{(6)}$

*Corresponding author: E-mail: dr.amanymohammed@gmail.com 
The aim of the study was to determinate the frequency and severity of depression, anxiety and stress in Egyptian patients with CLD and to assess the contribution of selected sociodemographic, disease-specific factors for depression, anxiety and stress.

\section{Subjects and methods:}

A cross-sectional study was done on adult patients (aged from 18 to 60 years old, geriatric group was excluded) attending Internal medicine outpatient clinic, Zagazig university hospital in the period from June to December 2018.

Sample size: based on expected frequency in depression among patients with CLD $(69.2 \%)^{(2)}$ and number of adult patients with CLD (aged from 18 to 60 years) attending outpatient clinic in 6 months was 800 , the sample size was 248 patients with power of the study $80 \%$ and $95 \%$ confidence interval. Patients were selected by systematic random technique with each third patient was selected. Exclusion criteria included the presence of already diagnosed psychiatric disorders (e.g., psychosis or dementia), acute complications of CLD, history of liver transplantation or using antiretroviral therapy.

Each patient had completed three questionnaires; the first one was a questionnaire containing personal characteristics such as age, gender and etiology of CLD was completed for each patient. The diagnosis of CLD was confirmed using combination of clinical signs and symptoms, laboratory investigations (enzymelinked immunosorbent assay [ELISA] and polymerase chain reaction [PCR] to diagnose hepatitis $\mathrm{C}$ virus (HCV), and hepatitis $\mathrm{B}$ surface antigen (HBsAg) to diagnose hepatitis B viral infection (HBV) and ultrasonography. The severity of liver disease was quantified using modified Child-Pugh classification ${ }^{(9)}$. The patients were stratified into the two groups: no cirrhosis/early cirrhosis (Child A) and advanced cirrhosis (Child B/Child C). Secondly, socioeconomic class was assessed using El-Gilany et al., ${ }^{(7)}$ questionnaire

The third questionnaire was the Depression Anxiety Stress Scale-21 (DASS-21). DASS21 was used to assess mental health. It includes 21 questions that measure anxiety, stress and depression separately, where each scale has seven questions. ${ }^{(8)}$ The overall score ranges from 0 to 21 . Scores $0-4,0-3$ and $0-7$ show normal levels of depression, anxiety and stress respectively; scores 5-7, 4-5 and 8-9 show low levels of depression, anxiety and stress respectively; scores of 8-11,5-7 and 10-13 show moderate levels of depression, anxiety and stress respectively; scores $12-15$, 
8-9 and 14-17 show severe levels of depression, anxiety and stress respectively; and scores of $25+, 10+$ and $18+$ show extreme severe levels of depression, anxiety and stress respectively. Scores for depression, anxiety and stress are calculated by adding the scores for the relevant items. ${ }^{(9)}$ The Arabic version of this tool has been psychometrically validated. $^{(10)}$

\section{Ethical considerations}

An official permission was obtained from faculty of Medicine, Zagazig University to accomplish this work. An informed consent was obtained from all the study participants after explaining study objectives and ensuring confidentiality of data. .

\section{Statistical analysis:}

Data analysis was performed using the software SPSS (Statistical Package for the Social Sciences) version 21. Quantitative variables were described using their means and standard deviations. Categorical variables were described using their absolute frequencies. To compare means of two groups, Mann Whitney test (for not normally distributed data) were used. For comparing of more than two groups, Kruskal Wallis test was used for not normally distributed data. To assess the correlation between patients' age and DASS-21 score, Spearman correlation coefficient was used. The level statistical significance was set at $5 \%(P \leq 0.05)$.

\section{Results:}

\section{Demographic characteristics of studied} patients: Mean age of patients was 46.35 ( \pm $8.01)$ years ranging from 32 to 63 years. The largest percentages of studied patients were male $(60.5 \%)$. Sixty five of them live in rural areas. The largest percentage of them were highly educated (24.6\%) followed by intermediate and basically educated (18.1\% each). Those who can read and write represent $(17.7 \%)$, those who received secondary education $(8.9 \%)$ then illiterate who represent $12.5 \%$ of studied patients. The largest percentage was married $(56 \%)$, single, divorced and widow were $11.3,14.5$ and 18.1 $\%$ respectively.

Regarding occupation, one fifth of them were skilled workers $(20.2 \%)$, more than one fourth work as semiprofessional (26.2\%), not working, unskilled workers, free business and professional represent $16.1,6.9,17.3$ and $13.3 \%$ respectively.

\section{Disease specific characteristics of studied} patients: About thirty seven percent of studied patients $(36.7 \%)$ had no cirrhosis, $39.5,23.8 \%$ of patients had compensated and decompensated cirrhosis respectively. The largest percentages of them had no comorbid 
diabetes mellitus or hypertension (73.8, $75.4 \%$ ) respectively. About thirty five percent (35.1\%) had Child A, 27.8\% and 37.1\% had Child B and C respectively. Seventy three percent of patients had hepatitis $\mathrm{C}, 17.3 \%$ of them had hepatitis B while only $9.7 \%$ had combined hepatitis $\mathrm{C}$ and $\mathrm{B}$. The studied patients had disease for duration ranged from 1 to 22 years with median 9 years

Frequency of depression, anxiety and stress in studied patients:

More than one fourth of cases had mild depression while $16.5 \%$ of them had moderate depression (figure 1). The same percentage reported extremely severe anxiety and severe stress (figures $2 \& 3$ ).

\section{Relation between sociodemographic characteristics and frequency of depression, anxiety and stress:}

There is non-significant positive correlation between age and DASS score but there is significant correlation between disease duration and DASS score (Table 1).

There are statistically significant differences between gender, education of the studied patients and mean depression, anxiety and stress scores. There are statistically nonsignificant differences between residence, social class, occupation, and marital status and each mean score of DASS scale (Table 2).
Relation between disease specific characteristics and frequency of depression, anxiety and stress:

There are statistically significant differences between presence of ascites, Child pough classification, comorbid diabetes mellitus and mean depression, anxiety and stress scores. There are statistically non-significant differences between viral cause and each mean score of DASS scale (Table 3).

Multivariate analysis of independent risk factors for development of depression, anxiety and stress in the studied patients:

Presence of comorbid diabetes and decompensated cirrhosis significantly increased the risk of depression by 3.84 and 17.7 folds respectively. On the other hand, absence of comorbid hypertension and being illiterate were protective factors against development of anxiety or stress. Additionally absence of comorbid diabetes mellitus protect against stress (table 4).

\section{Discussion}

Neuropsychological deficits in those patients usually include cognitive impairment and depression. These disorders occur as a consequence of accumulation neuropathogenic molecules and toxins in blood due to the inadequate clearance in a damaged liver. Similarly, immunological mechanisms, 
in patients with end stage liver disease, can lead to the development of depression. ${ }^{(2)}$

Bianchi et al. ${ }^{(12)}$ in their study of 156 patients with cirrhosis using two questionnaires (the Beck Depression Inventory and the Psychological General Well-Being Index) reported that the psychological condition of those patients is rigorously compromised. Signs of psychological distress and depression are correlated with $\mathrm{CP}$ classification.

Qureshi et al. ${ }^{(13)}$ studied 206 subjects divided in three groups. Group-I (chronic hepatitis C, $\mathrm{n}=95$ ), group-II (chronic hepatitis $\mathrm{B}, \mathrm{n}=29$ ) and group-III (healthy subjects, $\mathrm{n}=82$ ). They were matched for age, gender and socioeconomic status and were compared for frequency and severity of depression as measured by Hospital Anxiety and Depression Scale (HADS), found that only one fifth of their patients within group I and III reported moderate to severe depression.

In agreement with the current study, the frequency of anxiety was higher in male patients in another study. ${ }^{(2)}$

In the cross sectional study of 97 patients with CLD, Popović et al. ${ }^{(2)}$ reported that $62.9 \%$ of them had depression, while $13.4 \%$ of patients had anxiety. Further study of 63 patients with NASLD and 18 females with viral hepatitis reported high frequency of anxiety and depression among their patients. ${ }^{(14)}$

Namely, in patients with CLD, incidence of depression ranged from $20 \%$ to $70.6 \%(12,15$, ${ }^{17)}$ and anxiety from $13 \%$ to $71.6 \%{ }^{(15-16,18-20)}$. High proportion of patients with $\mathrm{CH}-\mathrm{C}$ had been diagnosed as having depression. ${ }^{(23)}$ Dwight et al. ${ }^{24}$ evaluated $50 \mathrm{CH}-\mathrm{C}$ patients using structured psychiatric interviews and standardized rating instruments, and found that $28 \%$ of their patients had current depressive disorders, and their disability and fatigue were more closely related to depression severity than to hepatic disease severity. El-Serag et al. ${ }^{(25)}$ reported that patients were more likely to have depressive disorders than controls. Another study assessing the association between different types of CLD with depression in a populationbased cohort showed that depression was strongly associated with $\mathrm{CH}-\mathrm{C} .{ }^{31}$ Furthermore, Golden et al. ${ }^{(27)}$ studied $90 \mathrm{CH}-$ C participants and demonstrated a $28 \%$ 1-month prevalence of depression, and $72 \%$ of whom were previously unidentified. Carta et al. ${ }^{(28)}$ provided the evidence that $\mathrm{CH}-\mathrm{C}$ was associated with MDD, independent of IFN- $\alpha$ treatment (32.6\%).

It is hypothesized that multiple factors are responsible for depression in hepatitis 
patients. Complexity, ambiguity, inconsistency and unpredictability of the course of illness, alterations in brain metabolites as evident by magnetic resonance imaging spectroscopy, and emotional factors and perception of stigma are thought to be the causes of depression in this population. ${ }^{(30)}$

On assessing relation between depression, anxiety and stress in relation to demographic and disease specific characteristics, no statistically significant difference was present between any of the studied scales and age, marital status, social class, occupation or viral cause.

Male gender, being educated, patients with comorbid diabetes, Child C, decompensated cirrhosis had significantly higher depression, anxiety and stress scores. Having depression is also associated with presence of anxiety among the studied patients.

There is statistically significant difference between presence of comorbid hypertension and anxiety score. Such difference was not present between comorbid hypertension and depression or stress scales.

The results from other study demonstrated that age had no relation with the severity of depression, which is consistent with our results. ${ }^{(16)}$
However, it was found that older patients have a significantly higher mean depression score than younger patients. ${ }^{(2)}$

Egyptian male patients had depressive symptoms more than female patients with the same disease. This can be explained by that male patients are financially responsible for their families and the nature of chronic liver disease as debilitating disease act as a physical, psychic as well as financial burden that threatens the whole family socioeconomic class and welfare.

Another study reported that there is no difference between gender and severity of depression, which is inconsistent with ours. ${ }^{(16)}$ On the other hand, a study in China revealed that female gender and socioeconomic status have been found to be significantly associated with depression. ${ }^{(31)}$ The reason for this difference may be in different biological and social factors between men and women ${ }^{(32)}$ respectively in greater responsibility to the health of women and the importance of their health on families and children

Also, educated patients had high concerns about their health as they read more about course, potential burden and further complications of their disease.

Presence of comorbid diabetes and progression of disease to cirrhosis lead to 
marked impairment of patients' health and use of additional medications.

In agreement of our findings, Qureshi et al. ${ }^{(13)}$ reported that patients with hepatitis $\mathrm{C}$ had more depression compared with those suffering from hepatitis B and controls.

These results are in accordance with a previous study that demonstrated that hepatitis C positive patients had more psychiatric disorders than hepatitis B positive patients. ${ }^{(28)}$ Carta et al. ${ }^{(28)}$ demonstrated the risk of major depressive disorder (MDD) was not statistically different between the chronic hepatitis B (CHB) group and controls. This study also indicates that the rate of depression across the combined $\mathrm{CHB}$ and chronic hepatitis $\mathrm{C}(\mathrm{CHC})$ patient group including a higher rate than that among healthy participants.

Atesci et al. ${ }^{(33)}$ found that inactive adult HBsAg carriers exhibited significantly greater depression than healthy controls; with HBV or HCV may not be the only cause of higher rates of depression in these patients. The chronic nature of the disease, stigmatization, or patients' perceptions of adverse outcomes of disease may be the additional causes.

In contrast to the current findings, there are controversial opinions about the way of liver disease severity affects the levels of depression and anxiety.

The strengths of this study include the homogeneous sample and the use of simple standardized questionnaire to diagnose symptoms of depression, anxiety and stress. To our knowledge, it is the first Egyptian study to assess psychiatric comorbidities in patients with CLD. However, the results should be interpreted with caution due to several limitations.

First, due to the cross-sectional design, the causality between psychiatric comorbidities and their correlates could not be identified. Second, depression, anxiety and stress were evaluated only by self-report, thus recall bias could not be excluded. Diagnosis of psychiatric disorders was bases on selfreported symptoms without official psychiatric consultation. Finally, some important variables, such as family support, have not been examined.

This study acts as base line for further large scale prospective studies to measure accurate incidence of psychiatric comorbidities in patients with CLD with professional psychiatric consultation.

\section{Conclusion:}

The largest percentage of patients with CLD reported psychiatric symptoms $(42.7 \%, 72.6 \%$ 
and $41.5 \%$ self-reported symptoms of depression, anxiety and stress respectively). Presence of comorbid diabetes mellitus and decompensated cirrhosis increase risk of depression by 3.84 and 17.7 fold respectively) while absence of comorbid hypertension and being illiterate were protective factors against development of anxiety and stress symptoms.

Conflict of interest: the authors declared no conflict of interest

Fund: the research is funded by the authors.

\section{References:}

1.Lee $\mathrm{K}$, Otgonsuren $\mathrm{M}$, Younoszai Z, Mir HM, and Younossi ZM. Association of chronic liver disease with depression: a population-based study. Psychosomatics 2013; 54, 52-59.

2.Popovi'c D, Culafi'c DM, Tepav`cevi'c DB, Kova cevi'c NV, Špuran MM, Djuranovi'c, SP, et al.: Assessment of depression and anxiety in patients with chronic liver disease. Vojnosanit. Pregl 2015; $72,414-420$.

3.Nardelli S, Pentassuglio I, Pasquale C, Ridola L, Moscucci F, Merli M, et al. Depression, anxiety and alexithymia symptoms are major determinants of health related quality of life (HRQoL) in cirrhotic patients. Metab. Brain Dis. 2013; 28, 239 243.

4.Miotto EC, Campanholo KR, Machado MA, Benute GG, Lucia MC, Fráguas R, et al.
Cognitive performance and mood in patients on the waiting list for liver transplantation and their relation to the model for end-stage liver disease. Arq Neuropsiquiatr 2010; 68(1): 62-6.

5.Stewart B, Turnbull D, Mikocka-Walus A, Hugh Harley, and Jane M. Andrews: An Aggravated Trajectory of Depression and Anxiety Co-morbid with Hepatitis C: A Within-groups Study of 61 Australian OutpatientsClin Pract Epidemiol Ment Health. 2015; 11: 174-179.

6.Navinés R, Castellví P, Moreno-España J, Gimenez D, Udina $M$, Cañizares $S$, et al. Depressive and anxiety disorders in chronic hepatitis $\mathrm{C}$ patients: reliability and validity of the Patient Health Questionnaire. J Affect Disord 2012; 138(3): 343-51.

7.Pugh RN, Murray-Lyon IM, Dawson JL, Pietrini MC, Williams R. Transection of the esophagus for bleeding oesophageal varices. Br J Surg. 1973; (60):646-649.

8.El-GilanyA, El-Wehady A, El-Wasify, M (2012). Updating and validation of the socioeconomic status scale for health research in Egypt. East Mediterr Health J. 2012;18(9):962-8.

9.Lovibond PF, Lovibond SH. The structure of negative emotional states: Comparison of the Depression Anxiety Stress Scales (DASS) with the Beck Depression and Anxiety Inventories. Behaviour Research and Therapy 1995; (33):335-343.

10. Ali A and Green J. Differential Item Functioning of the Arabic Version of the 
Depression Anxiety Stress Scale-21 (DASS21). Nursing \& Health Care. 2017; 4 (5) :1-4

11.Weinstein AA, Kallman PJ, Stepanova M, Poms LW, Fang Y, Moon J, et al. Depression in patients with nonalcoholic fatty liver disease and chronic viral hepatitis $\mathrm{B}$ and $\mathrm{C}$. Psychosomatics 2011; 52(2): 127-32.

12.Bianchi G, Marchesini G, Nicolino F, Graziani R, Sgarbi D, Loguer-cio C, et al. Psychological status and depression in patients with liver cirrhosis. Dig Liver Dis 2005; 37(8): 593-600.

13.Qureshi MO, Khokhar N, Shafqat F. Severity of depression in hepatitis B and hepatitis $\mathrm{C}$ patients. Journal of the College of Physicians and Surgeons-Pakistan 2012; 22(10): 632-634.

14.Surdea-Blaga T, Dumitraşcu DL. Depression and anxiety in nonalcoholic steatohepatitis: is there any association. Rom J Intern Med 2011; 49(4): 273-80.

15.Dogar I, Siddiqui N, Bajwa A, Bhatti A, Haider N, Hashmi ZY. Relationship between liver diseases and levels of anxiety and depression. J Pak Psych Soc 2009; 6(2): 61-4.

16.DiMartini A, Dew MA, Javed L, Fitzgerald MG, Jain A, Day N. Pretransplant psychiatric and medical comorbidity of alcoholic liver disease patients who received liver transplant. Psy-chosomatics 2004; 45(6): 517-23.

17. Martins PD, Sankarankutty AK. Silva Ode C, Gorayeb R. Psychological distress in patients listed for liver transplantation. Acta Cir Bras 2006; 21(Suppl 1): 40-3.
18.Saunders JC. Neuropsychiatric symptoms of hepatitis C. Is-sues Ment Health Nurs 2008; 29(3): 209-20.

19.Tillmann HL, Wiese M, Braun Y, Wiegand J, Tenckhoff S, Mössner J, et al. Quality of life in patients with various liver diseases: patients with $\mathrm{HCV}$ show greater mental impairment, while patients with $\mathrm{PBC}$ have greater physical impairment. J Viral Hepat 2011; 18(4): 252-61.

20.Martín-Santos R, Díez-Quevedo C, Castellví P, Navinés R, Miquel M, Masnou H, et al. De novo depression and anxiety disorders and influence on adherence during peginterferon-alpha- $2 \mathrm{a}$ and ribavirin treatment in patients with hepatitis C. Aliment Pharmacol Ther 2008; 27(3): 257-65.

21.Beloborodova EI, Lambrova EG, Beloborodova EV, Ostanko VL, Alekseeva AS, Kalacheva TP, et al. Somatopsychic manifesta-tions in patients with chronic viral hepatitis. Klin Med (Mosk) 2010; 88(5): $42-5$.

22.Shi X, Xun J, Wang S, Zhang J. Study on depression in 212 pa-tients with viral hepatitis. Zhonghua Liu Xing Bing Xue Za Zhi 2009; 30(10): 1060-4.

23.Schaefer M, Capuron L, Friebe A, DiezQuevedo C, Robaeys G, Neri S, et al. Hepatitis $\mathrm{C}$ infection, antiviral treatment and mental health: a European expert consensus statement. J. Hepatol.2012; 57, 1379-1390.

24. Dwight, MM, Kowdley KV, Russo J E, Ciechanowski PS, Larson AM, and Katon WJ. Depression, fatigue, and functional 
disability in patients with chronic hepatitis $\mathrm{C}$. J. Psychosom. Res.2000; 49, 311-317.

25. El-Serag HB, Kunik M, Richardson P, Rabeneck L. Psychiatric disorders among veterans with hepatitis $\mathrm{C}$ infection. Gastroenterology. 2002;123, 476-482.

26. Lee K, Otgonsuren M, Younoszai Z, Mir HM, Younossi ZM. Association of chronic liver disease with depression: a population-based study. Psychosomatics 2013; 54, 52-59.

27. Golden J, O'Dwyer, AM, Conroy R $\mathrm{M}$. Depression and anxiety in patients with hepatitis C: prevalence, detection rates and risk factors. Gen. Hosp. Psychiatry 2005; 27, 431-438.

28. Carta, M. G., Hardoy, M. C., Garofalo, A., Pisano, E., Nonnoi, V., Intilla, G., et al. Association of chronic hepatitis $\mathrm{C}$ with major depressive disorders: irrespective of interferon-alpha therapy. Clin. Pract. Epidemiol. Ment. Health, 2007; 3:22-26.

29. Wessley S, Pariante C. Fatigue, depression and chronic hepatitis $\mathrm{C}$ infection. Psychol Med 2002; 32:1-10

30. Forton DM, Hamilton G, Allsop JM, Grover VP, Wesnes K, O'Sullivan C, et al. Cerebral immune activation in chronic hepatits $\mathrm{C}$ infection: a magnetic resonance spectroscopy study. J Hepatol 2008; 49:31622.

31.Ma X, Xiang YT, Cai ZJ, Li SR, Xiang YQ, Guo H.L., et al. Prevalence and sociodemographic correlates of major depressive episode in rural and urban areas of Beijing, China. Journal of Affective Disorders 2009; 115(3), 323-330.

32.Zhong, B, Liu TB, Chan SS, Jin D, Hu CY, Dai J, et al. Prevalence and correlates of major depressive disorder among rural-to-urban migrant workers in Shenzhen, China. Journal of Affective Disorders, 2015; 183, 1-9.

33.Parker G, Brotchie H. Gender differences in depression. Int Rev Psychiatry 2010; 22(5): 429-36. 


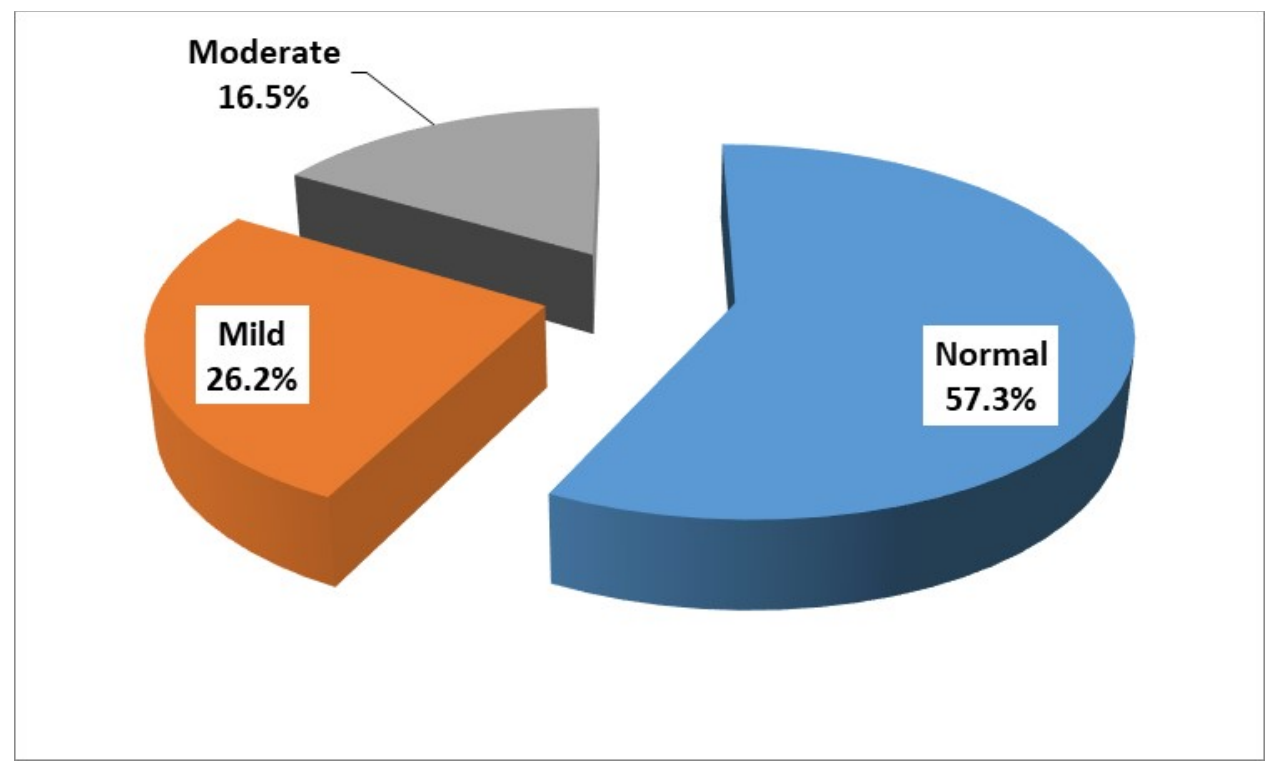

Figure (1) Pie chart showing distribution of the studied patients according to self-reported depression level

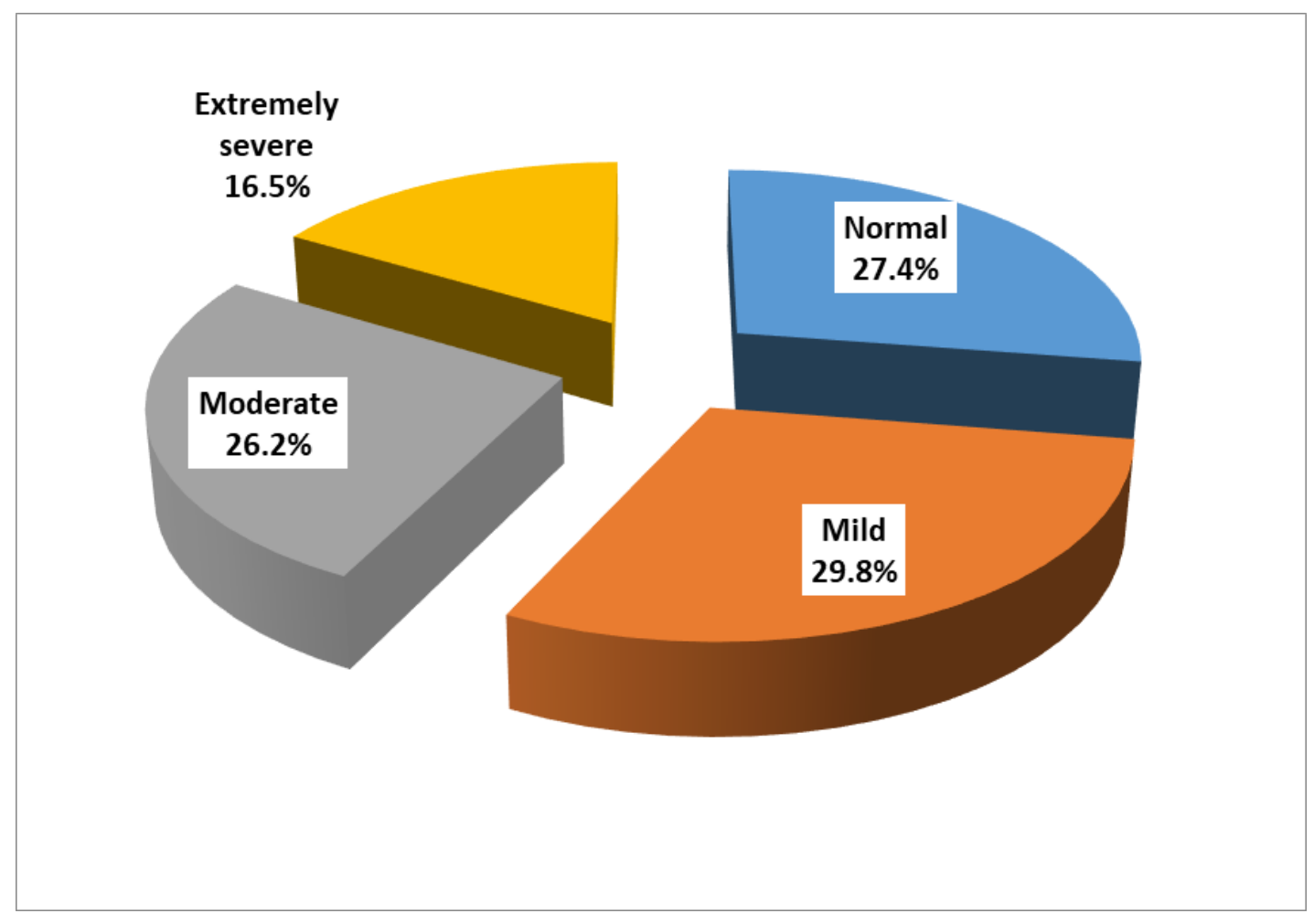

Figure (2) Pie chart showing distribution of the studied patients according to self-reported anxiety level 


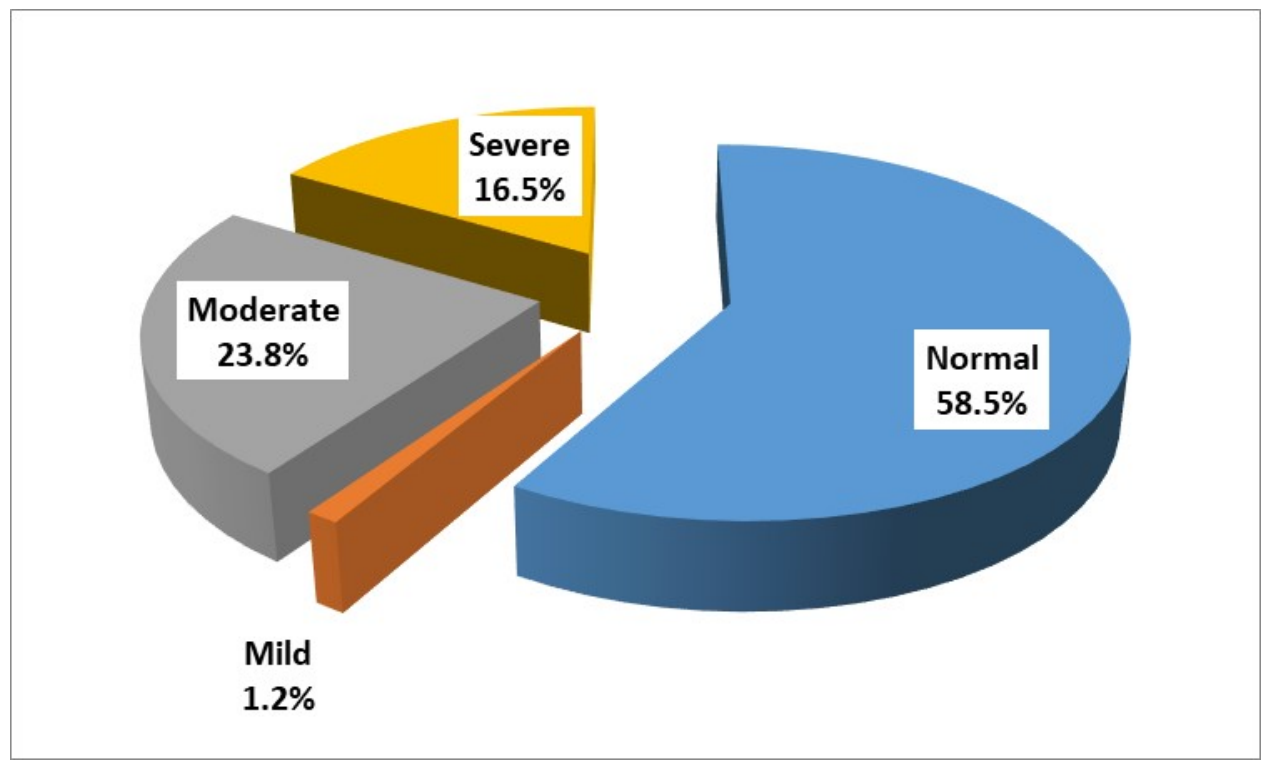

Figure (3) Pie chart showing distribution of the studied patients according to self-reported stress level

Table (1): Correlation between age, disease duration and DASS score among the studied patients

\begin{tabular}{|l|c|c|c|c|c|c|}
\hline & \multicolumn{2}{|c|}{ Depression } & \multicolumn{2}{c|}{ Anxiety } & \multicolumn{2}{c|}{ Stress } \\
\hline & r & p & r & p & r & p \\
\hline Age & 0.027 & 0.678 & 0.047 & 0.459 & 0.051 & 0.426 \\
\hline Disease duration & 0.151 & $\mathbf{0 . 0 1 7}$ & 0.127 & $\mathbf{0 . 0 4 6}$ & 0.125 & $\mathbf{0 . 0 4 9}$ \\
\hline
\end{tabular}


Table (2): Relation between DASS score and demographic characteristics of studied patients

\begin{tabular}{|c|c|c|c|c|c|c|c|c|c|}
\hline \multirow[t]{2}{*}{$\begin{array}{l}\text { Sociodemographic } \\
\text { characteristics }\end{array}$} & $\begin{array}{l}\text { Depression } \\
\text { score }\end{array}$ & \multirow[t]{2}{*}{ Test } & \multirow[t]{2}{*}{$\mathbf{p}$} & \multirow{2}{*}{$\begin{array}{l}\begin{array}{l}\text { Anxiety } \\
\text { score }\end{array} \\
\text { Mean } \pm \text { SD } \\
\end{array}$} & \multirow[t]{2}{*}{ Test } & \multirow[t]{2}{*}{$\mathbf{p}$} & \multirow{2}{*}{$\begin{array}{l}\text { Stress score } \\
\text { Mean } \pm \text { SD } \\
\end{array}$} & \multirow[t]{2}{*}{ Test } & \multirow[t]{2}{*}{$\mathbf{p}$} \\
\hline & Mean \pm SD & & & & & & & & \\
\hline $\begin{array}{l}\text { Gender: } \\
\text { Male } \\
\text { Female }\end{array}$ & $\begin{array}{l}10.43 \pm 6.93 \\
8.48 \pm 7.03\end{array}$ & $-2.053^{¥}$ & 0.04 & $\begin{array}{l}10.31 \pm 6.83 \\
8.51 \pm 6.75\end{array}$ & $-2.335^{¥}$ & 0.02 & $\begin{array}{l}10.31 \pm 6.93 \\
8.35 \pm 6.79\end{array}$ & $-2.203^{¥}$ & 0.028 \\
\hline $\begin{array}{l}\text { Residence: } \\
\text { Rural } \\
\text { Urban } \\
\end{array}$ & $\begin{array}{l}10.18 \pm 7.06 \\
8.99 \pm 6.94\end{array}$ & $-1.196^{¥}$ & 0.232 & $\begin{array}{l}10.24 \pm 6.79 \\
8.78 \pm 6.85 \\
\end{array}$ & $-1.699^{¥}$ & 0.089 & $\begin{array}{l}10.22 \pm 6.91 \\
8.65 \pm 6.88 \\
\end{array}$ & $-1.796^{¥}$ & 0.072 \\
\hline $\begin{array}{l}\text { social class: } \\
\text { low } \\
\text { middle } \\
\text { high }\end{array}$ & $\begin{array}{l}9.85 \pm 7.44 \\
9.58 \pm 6.74 \\
8.63 \pm 5.11 \\
\end{array}$ & $0.205^{*}$ & 0.902 & $\begin{array}{l}9.78 \pm 7.23 \\
9.64 \pm 6.6 \\
8.05 \pm 4.75 \\
\end{array}$ & $0.633^{*}$ & 0.726 & $\begin{array}{l}9.71 \pm 7.34 \\
9.62 \pm 6.66 \\
7.84 \pm 4.82 \\
\end{array}$ & $1.521^{*}$ & 0.467 \\
\hline $\begin{array}{l}\text { Education: } \\
\text { Illiterate } \\
\text { educated }\end{array}$ & $\begin{array}{l}7.13 \pm 8.75 \\
10.02 \pm 6.68\end{array}$ & $-2.302^{¥}$ & 0.021 & $\begin{array}{l}7.77 \pm 8.45 \\
9.86 \pm 6.56 \\
\end{array}$ & $-2.263^{¥}$ & 0.024 & $\begin{array}{l}7.65 \pm 8.48 \\
9.8 \pm 6.66\end{array}$ & $-2.146^{¥}$ & 0.032 \\
\hline $\begin{array}{l}\text { Occupation: } \\
\text { Not working } \\
\text { Unskilled worker } \\
\text { Skilled worker } \\
\text { Clerk } \\
\text { Semiprofessional } \\
\text { Professional } \\
\end{array}$ & $\begin{array}{l}10.6 \pm 8.71 \\
10.58 \pm 8.12 \\
9.88 \pm 7.85 \\
9.14 \pm 6.85 \\
9.2 \pm 4.15 \\
8.58 \pm 7.45 \\
\end{array}$ & $2.709^{*}$ & 0.745 & $\begin{array}{l}11.2 \pm 8.13 \\
10.12 \pm 7.54 \\
10.24 \pm 8.12 \\
9.16 \pm 6.86 \\
8.98 \pm 3.92 \\
8.21 \pm 7.21 \\
\end{array}$ & $3.247^{*}$ & 0.662 & $\begin{array}{l}11 \pm 8.33 \\
10.12 \pm 7.54 \\
10.34 \pm 8.24 \\
9.05 \pm 6.89 \\
8.98 \pm 4.03 \\
7.94 \pm 7.16 \\
\end{array}$ & $3.023^{*}$ & 0.696 \\
\hline $\begin{array}{l}\text { Marital status: } \\
\text { Single } \\
\text { Married } \\
\text { Divorced } \\
\text { Widow } \\
\end{array}$ & $\begin{array}{l}9.29 \pm 5.26 \\
9.55 \pm 7.15 \\
10.53 \pm 6.54 \\
9.51 \pm 8.03\end{array}$ & $0.761^{*}$ & 0.859 & $\begin{array}{l}9.35 \pm 5.19 \\
9.38 \pm 7 \\
10.56 \pm 6.15 \\
9.67 \pm 7.82 \\
\end{array}$ & $1.093^{*}$ & 0.779 & $\begin{array}{l}9.21 \pm 5.3 \\
9.27 \pm 7.04 \\
10.75 \pm 6.38 \\
9.56 \pm 6.93 \\
\end{array}$ & $1.729^{*}$ & 0.631 \\
\hline
\end{tabular}

${ }^{¥}$ Mann Whitnet test ${ }^{*}$ Kruskal Wallis test 
Table (3): Relation between DASS score and disease specific characteristics of studied patients

\begin{tabular}{|c|c|c|c|c|c|c|c|c|c|}
\hline \multirow{2}{*}{$\begin{array}{l}\text { Disease } \\
\text { specific } \\
\text { characteristics }\end{array}$} & $\begin{array}{l}\text { Depression } \\
\text { score }\end{array}$ & \multirow[t]{2}{*}{ Test } & \multirow[t]{2}{*}{$\mathbf{p}$} & $\begin{array}{l}\text { Anxiety } \\
\text { score }\end{array}$ & \multirow[t]{2}{*}{ Test } & \multirow[t]{2}{*}{$\mathbf{p}$} & Stress score & \multirow[t]{2}{*}{ Test } & \multirow[t]{2}{*}{$\mathbf{p}$} \\
\hline & Mean \pm SD & & & Mean \pm SD & & & Mean \pm SD & & \\
\hline $\begin{array}{l}\text { Diabetes } \\
\text { mellitus: } \\
\text { Absent } \\
\text { Present } \\
\end{array}$ & $\begin{array}{l}8.44 \pm 7.43 \\
13.09 \pm 6.65 \\
\end{array}$ & $-4.629^{¥}$ & $<0.001$ & $\begin{array}{l}8.47 \pm 6.53 \\
12.78 \pm 6.63 \\
\end{array}$ & $-4.212^{¥}$ & $<0.001$ & $\begin{array}{l}8.43 \pm 6.63 \\
12.63 \pm 6.84 \\
\end{array}$ & $-4.063^{¥}$ & $<0.001$ \\
\hline $\begin{array}{l}\text { Hypertension: } \\
\text { Absent } \\
\text { Present } \\
\end{array}$ & $\begin{array}{l}9.28 \pm 7.04 \\
10.8 \pm 6.89 \\
\end{array}$ & $-1.775^{¥}$ & 0.079 & $\begin{array}{l}9.13 \pm 6.96 \\
11.5 \pm 6.29 \\
\end{array}$ & $-2.397^{¥}$ & 0.017 & $\begin{array}{l}9.14 \pm 7.04 \\
10.74 \pm 6.48\end{array}$ & $-1.681^{¥}$ & 0.093 \\
\hline $\begin{array}{l}\text { Cirrhosis: } \\
\text { Absent } \\
\text { Compensated } \\
\text { Decompensated }\end{array}$ & $\begin{array}{l}4.32 \pm 4.25 \\
9.94 \pm 5.75 \\
17.42 \pm 4.5\end{array}$ & $123.23^{*}$ & $<0.001$ & $\begin{array}{l}4.32 \pm 3.82 \\
9.98 \pm 5.64 \\
17.12 \pm 4.68\end{array}$ & $128.15^{*}$ & $<0.001$ & $\begin{array}{l}4.24 \pm 4.05 \\
9.97 \pm 5.7 \\
16.97 \pm 4.92\end{array}$ & $126.76^{*}$ & $<0.001$ \\
\hline $\begin{array}{l}\text { Child Pough: } \\
\text { A } \\
\text { B } \\
\text { C }\end{array}$ & $\begin{array}{l}4.43 \pm 5.3 \\
9.94 \pm 6.21 \\
14.39 \pm 5.43 \\
\end{array}$ & $95.726^{*}$ & $<0.001$ & $\begin{array}{l}4.75 \pm 5.16 \\
9.65 \pm 6.06 \\
14.15 \pm 5.57 \\
\end{array}$ & $88.044^{*}$ & $<0.001$ & $\begin{array}{l}4.56 \pm 5.19 \\
9.75 \pm 6.15 \\
14.06 \pm 5.66\end{array}$ & $89.828^{*}$ & $<0.001$ \\
\hline $\begin{array}{l}\text { Viral cause: } \\
\text { HBV } \\
\text { HCV } \\
\text { Combined }\end{array}$ & $\begin{array}{l}9.6 \pm 6.48 \\
9.64 \pm 6.97 \\
9.92 \pm 8.49\end{array}$ & $0.066^{*}$ & 0.967 & $\begin{array}{l}9.47 \pm 6.36 \\
9.59 \pm 6.76 \\
9.96 \pm 8.45\end{array}$ & $0.078^{*}$ & 0.962 & $\begin{array}{l}9.53 \pm 6.5 \\
9.49 \pm 6.84 \\
9.88 \pm 8.48 \\
\end{array}$ & $0.001^{*}$ & 0.999 \\
\hline
\end{tabular}

$\mathrm{X}^{2}$ : chi square, OR: Crude Odds Ratio, CI: confidence interval, $\mathrm{r}=$ reference group 
Table (4): Multivariate analyses of factors independently predict presence of depression in patients with chronic liver disease

\begin{tabular}{|c|c|c|c|}
\hline \multicolumn{4}{|c|}{ Depression } \\
\hline & OR & $95 \%$ CI & $\mathbf{p}$ \\
\hline Diabetes mellitus & 3.84 & $1.4-10.26$ & 0.007 \\
\hline Decompensated cirrhosis & 17.7 & $2.3-136.01$ & 0.006 \\
\hline \multicolumn{4}{|c|}{ Anxiety } \\
\hline Absence of comorbid Hypertension & 0 & $0-$ & 0.999 \\
\hline illiterate & 0 & $0-$ & 0.999 \\
\hline \multicolumn{4}{|c|}{ Stress } \\
\hline Absence of comorbid diabetes & 0 & $0-$ & 0.999 \\
\hline Absence of comorbid Hypertension & 0 & $0-$ & 0.998 \\
\hline Illiterate & 0 & $0-$ & 0.999 \\
\hline
\end{tabular}


العربى الملخص

الاكتئاب والقلق والتوتر لاي المرضي المصريين المصابين بامراض الكبد المزمنة

أماني محمد عبدالله , محمود احمد شرف الدين

المقدمة يعاني معظم المرضي المصابين بامر اض الكبد المزمنة من درجات مختلفة من الاكتئاب والقلق.الاهداف:تحديد معدل انتشار الاكتئاب ,القلق والتوتر بين المرضي المصابين بامر اض الكبد المزمنه وايجاد العلاقة بينهم وبين الخصائص الديموغر افية و المتعلقة بالمرض كذلك

منهجية الاراسة:تمت هذه الدر اسة المقطعيه بعيادات الأمر اض الباطنية بمستشفي جامعة الزقازيق خلال الفترة من اول يونيو حني اخر ديسمبر 2018. نم استخدام استبيان لجمع البيانات الثخصية وسبب المرض واستبيان اخر لتقييم الحالة النفسية للمرضيز تم توقيع الفحص السريري للمرضي واجر اء الفحوصات المعملية والاشعة التليفزيونية. تم تحديد شدة مرض الكبد باستخدام تصنيف تشايلد المعدل.

النتائج: اظهرت النتائج ان حوالي 16.5\% من المرضي يعانون من درجة منوسطة من الاكتئاب و نفس النسبة تعاني ايضا من درجات شديدة من القلق والتوتر. هناك علاقة ذات قيمة احصائية بين معدلات الاكتئاب, القلق والتونر وكلا من جنس ,تعليم المريض, تصنيف ثشايلد لشدة المرض,وجود الاستسقاء و مرض السكري. الخلاصة: يعاني معظم المرضي الذين اشتملتهم الرسالة من الاكتئاب والقلق والتوتر. وجود مرض السكري والتليف غير المتكافئ يزيد من فرص حدوث الاكتئاب ب 3.48 و 17.7 ضعف مقارنة بمن لا يعاني من هذه المشاكل علي الترتيب. كون المريض أمي او لا يعاني من ملرض الرتفاع ضغط الدم يقلل من فرص حدوث القلق و التوثر لدي المرضي. 